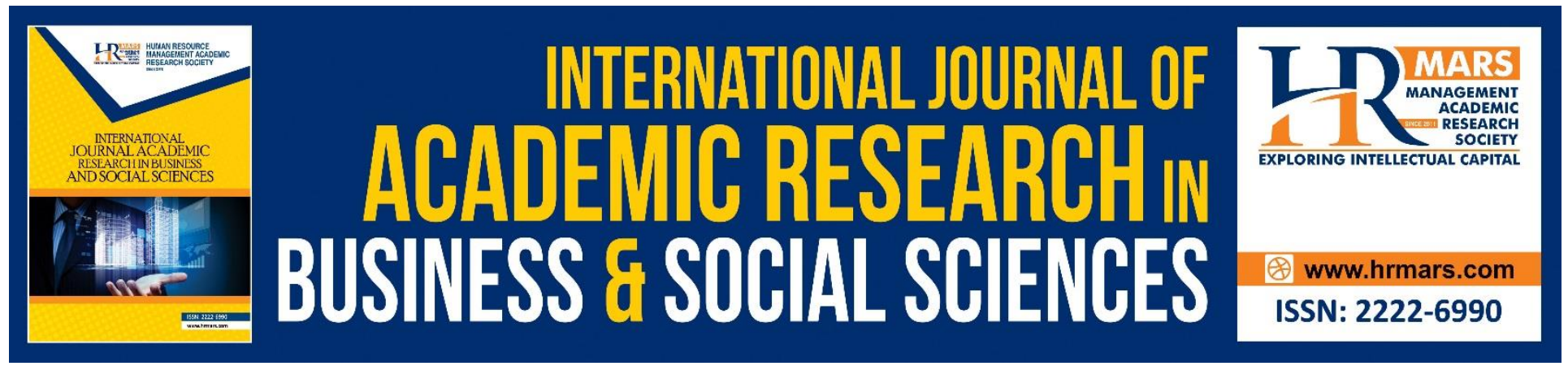

\title{
Entrepreneurial Orientation, Business Strategy, and Small Medium Enterprise's Performance
}

Ida Bagus Agung Dharmanegara, I Made Yogiarta, I Made Setena

To Link this Article: http://dx.doi.org/10.6007/IJARBSS/v8-i11/4923

DOI: $10.6007 /$ IJARBSS/v8-i11/4923

Received: 07 Oct 2018, Revised: 24 Oct 2018, Accepted: 26 Nov 2018

Published Online: 28 Nov 2018

In-Text Citation: (Dharmanegara, Yogiarta, \& Setena, 2018)

To Cite this Article: Dharmanegara, I. B. A., Yogiarta, I. M., \& Setena, I. M. (2018). Entrepreneurial Orientation, Business Strategy, and Small Medium Enterprise's Performance. International Journal of Academic Research in Business and Social Sciences, 8(11), 484-494.

Copyright: (C) 2018 The Author(s)

Published by Human Resource Management Academic Research Society (www.hrmars.com)

This article is published under the Creative Commons Attribution (CC BY 4.0) license. Anyone may reproduce, distribute, translate and create derivative works of this article (for both commercial and non-commercial purposes), subject to full attribution to the original publication and authors. The full terms of this license may be seen

at: http://creativecommons.org/licences/by/4.0/legalcode

Vol. 8, No. 11, 2018, Pg. 484 - 494

http://hrmars.com/index.php/pages/detail/IJARBSS

JOURNAL HOMEPAGE

Full Terms \& Conditions of access and use can be found at http://hrmars.com/index.php/pages/detail/publication-ethics 


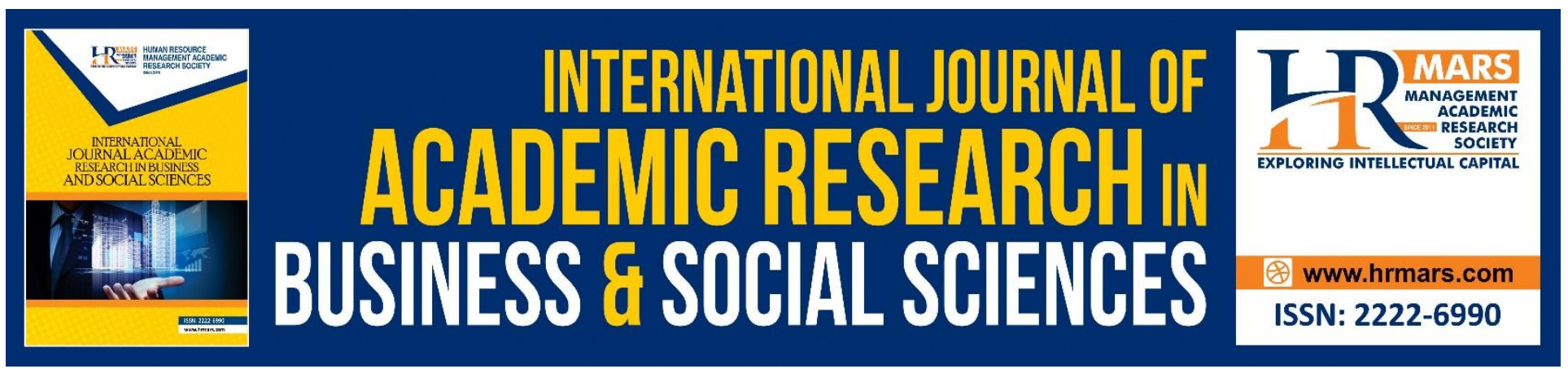

\title{
Entrepreneurial Orientation, Business Strategy, and Small Medium Enterprise's Performance
}

\author{
Ida Bagus Agung Dharmanegara, I Made Yogiarta, I Made Setena \\ Faculty of Economic, Warmadewa University, Denpasar, Bali, Indonesia
}

\begin{abstract}
There are determining factors that are directly related to the generation of opportunities that maximize performance of the small medium enterprise (SME). This research paper focuses on a quantitative paradigm to measure the entrepreneurial orientation, business strategy and SMEs' performance as variables. A causal model was developed from the literature, from which a set of hypotheses was posed and a questionnaire was made. A sample of 95 small and medium entreprise in Denpasar was subject to the questionnaire. The findings suggest, entrepeneurial orientation have the most important effect on marketing performance rather than business strategy. The results are based on a rather small sample of exporting SMEs in Denpasar Bali; therefore, the generalizability of the results cannot be assured. But this study will sheds more light on the little researched themes of entrepreneurial orientations in the context of SMEs.
\end{abstract}

Keywords: Entrepreneurial Orientation, Business Strategy, Small Medium Enterprise, Marketing Performance.

\section{Introduction}

Small-and medium-sized enterprises (SMEs) are seemed to be the engines of economic growth, which it not yet achieved the desired trajectory of success. Despite of being positioned at the centre of attention by the governments with massive support, the underlying perceptions of SMEs' owner in developing provisions to recover are less well understood. Small firms are frequently faced with restrictions such as skill shortages, difficulties in attracting staff, funding issues and continuous changes in the supply chain and industry, and therefore need to utilise all potential factors that may help to overcome these constraints. SMEs have to struggle and compete with larger enterprises in a different and niche arena through product innovativeness and competitiveness (Wagner \& Hansen, 2005).

Despite the difficulties in comparing data between one country and another, there are general patterns in the relative productivity and distribution of firms by size among the region's SMEs. It is not only self-evident that every small firm aims to grow, but also it has demonstrated their ability to cope with economic turbulences successfully. As Verreynne \& Meyer (2010) argued that performance differences in small firms are often the subject of research, media attention and government policy. 
INTERNATIONAL JOURNAL OF ACADEMIC RESEARCH IN BUSINESS AND SOCIAL SCIENCES Vol. 8, No. 11, Nov, 2018, E-ISSN: 2222-6990 @ 2018 HRMARS

The importance of identifying those factors that may provide small firms with a competitive advantage cannot be overstated.

In understanding of the many factors that influence small to medium-sized enterprise (SME) performance and growth, Blackburn et al., (2013) argued that size and age of enterprise have dominant effect on performance and these are more important than strategy and the entrepreneurial characteristics of the owner. Entrepreneurship literature suggests marketing to be one of the pivotal predictors of business performance (Gilmore, 2011). Part of a heterogeneous universe of extremely diverse economic agents, whose characteristics vary depending on the business sector they operate in, the markets they serve, and the products they produce. In practice entrepreneurs in SME are more focused on trying to be innovative, especially in relation to differentiating their products and company from the competitors. This is related with how the value generated and product or service is presented within the scope of the product/service offering. Many different views are existed, from both practitioners and academics (Gilmore, 2011), in how conceptually position the relationships marketing is part of entrepreneurship and entrepreneurship involves marketing.

.Entrepreneurial orientation (EO) refers to the strategic orientation of a firm, capturing the entrepreneurial aspects of decision-making styles, methods, and practices in specific ways (Wiklund and Shepherd, 2005). While most entrepreneurial studies consider entrepreneurial orientation to be a unified concept (Covin and Slevin 1989; Wiklund 1999), the notion of a single factor concept of entrepreneurial orientation has also been examined in several studies, especially with regard to the three dimensions of entrepreneurial orientation that could vary independently from one to another (Krauss et al 2005; Lumpkin and Dess 1996; Lyon et al. 2000). In particular, Lumpkin and Dess (1996) explained that companies that have a stronger entrepreneurial orientation tend to be more daring to take risks, not only survive on past strategies. In a dynamic environment like today, entrepreneurial orientation is clearly plays important role for facing the dynamic and turbulence of market competition. Wiklund and Shepherd (2005) identify a positive relationship between entrepreneurial orientation and business performance, as well as research findings revealed by Wiklund (1999). Previous research shows weak relationship between entrepreneurial orientation and company performance (Lumpkin \& Dess, 1996). The gap makes researchers more interested in testing the relationship of entrepreneurial orientation on business performance, especially in terms of the marketing performance of small micro businesses.

The phenomenon of problems in some of the results of previous studies as described above also occurs in superior micro-industries, especially in Denpasar, Bali, Indonesia. Small-scale industries in Indonesia have experienced a significant development with the continued growth of the business world which was marked by the increasingly new business start-ups in various places that showed the dynamics of business competition. The previous condition of small businesses as exlpained above triggered the curiosity of researchers in order to explore entrepreneurial orientation, business strategy and marketing performance as integrated concepts observed in a research model. Therefore, past research conducted under any of the preceding labels will be considered research examining entrepreneurial orientation (Suci, 2009; Wiklund \& Shepherd, 2005; Wiklund, 1999).

The aim of this paper is to examine how SMEs with different marketing performance differ from each other regarding entrepreneurial orientation and business strategy. The study investigates 
INTERNATIONAL JOURNAL OF ACADEMIC RESEARCH IN BUSINESS AND SOCIAL SCIENCES

Vol. 8, No. 11, Nov, 2018, E-ISSN: 2222-6990 @ 2018 HRMARS

whether in those small firms where marketing performance is seen as an important goal they have also adopted entreprenurial orientation. Both of this orientation and strategy are estimated to lead to enhanced marketing performance.

\section{Literature Review}

\section{Entrepreneurial Orientation}

The entrepreneurial orientation concept built upon previous research that viewed strategy making in terms of patterns of action or decision making styles that are suitable across organizations. Understanding of the ways in which several behavioral and psychological characteristics coud influence the entrepreneurial intention will help to advance our knowledge in the entrepreneurial process (Ferreira, Raposo, Rodrigues, Dinis, \& Paco, 2012). Entrepreneurial orientation defined as processes, propensities and behaviors that lead to entry into new or established or competitive markets with new or existing goods or services (Lumpkin and Dess, 1996). Many entrepreneurship studies postulate a strong EO performance relationship, especially in hostile and or technologically sophisticated environments (Walter et al., 2006). Many previous authors argue that entrepreneurial behavior such entrepreneurial orientation is important for firms of all sizes to prosper in competitive environments (Lumpkin \& Dess, 1996, 2001; Lyon, Lumpkin, \& Dess, 2000). Besides, previous empirical finding such as Ferreira et al., (2012) argued that contribution of behavioural and psychological theories to the entrepreneurial intention, in their findings reveals need for achievement, self-confidence, and personal attitude positively affect entrepreneurial intention.

Lumpkin \& Dess, (1996) attempted to clarify confusion in terms, thus giving a clear distinction between entrepreneurial orientation and entrepreneurship. Lumpkin \& Dess, (2001) have defined entrepreneurial orientation as a form of entrepreneurial activity of a business entity related to product innovation, carrying out risky activities and the first in introducing proactive innovation. Entrepreneurial orientation could also be derived in 4 components, which are readiness to face uncertainty situations, ability to handle risk, personal responsibility and business problem solving ability (Sagie \& Elizur, 1999). Thus it can be concluded that the key dimensions of entrepreneurial orientation include the willingness to be independent (autonomy), the desire to innovate (innovativeness), the tendency to be aggressive towards competitors (competitive aggressiveness), and being proactive towards market opportunities (proactiveness). Ejdys, (2016) has tested the entrepreneurial orientation which is associated with the form of strategy that is organizational innovation. Entrepreneurial orientation is seen as two important things, namely risk taking and proactive, both of which have a causality relationship. The findings reveal that both proactive and risk taking have an important impact on organizational innovation. But Ejdys, (2016) also asserts that risk taking has the biggest role in increasing one's proactive attitude.

\section{Small Business Strategy}

Verreynne \& Meyer, (2010) argues that small firms could do make strategy, and instead of formal processes, they use this kind of approaches that are more suitable to their unique circumstances. Previous empirical finding such as Suci (2009) reveals that entrepreneurial orientation has important effect on business strategy in small and medium-sized in East Java. Thus, entrepreneurs develop and succeed because they have adequate research and development capabilities so that they could 
INTERNATIONAL JOURNAL OF ACADEMIC RESEARCH IN BUSINESS AND SOCIAL SCIENCES

Vol. 8, No. 11, Nov, 2018, E-ISSN: 2222-6990 @ 2018 HRMARS

create and apply the right business strategies to create valuable and superior goods in the market. Berger, Hasan, \& Zhou, (2010) examined the effect of focus versus diversification strategies on company performance, revealing that companies using focus strategies are associated with higher profits, lower costs, and higher efficiency. While companies with diversification strategies generate lower profits and higher costs.

\section{Marketing Performance}

Pearce \& Robinson (2007) looks for growth theory of company that looking at organization as a life cycle or developmental model. Kotler \& Keller (2012) describe metrics in marketing as a measurement tool that helps in calculating, comparing, and interpreting marketing performance. Best (2009) suggests that marketing performance is a market metric that records customer behavior, in which turned as indicator of financial performance. Wiklund \& Shepherd (2005) revealed the positive relationship between entrepreneurial orientation and business performance, in line with previous findings (Wiklund, 1999). Ferdinand (2002) explained that good marketing performance is expressed in three main indicators, which are : customer growth, sales growth, and market share.

\section{Hypotheses Development}

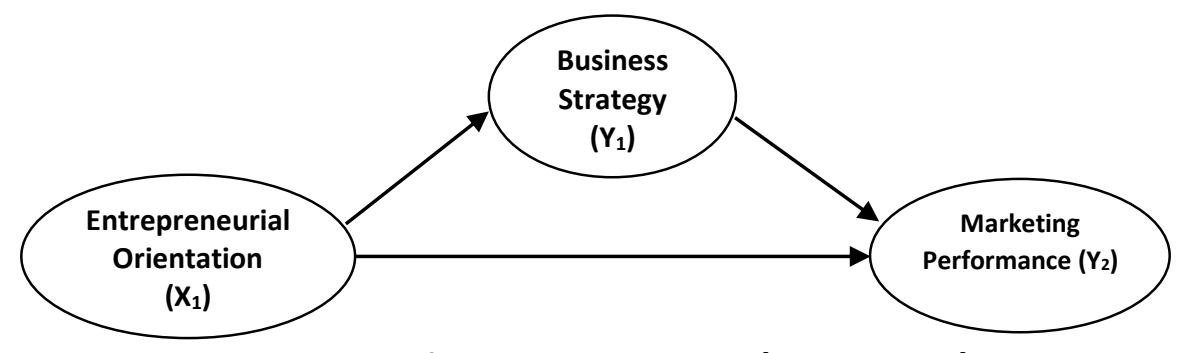

Figure 1: Conceptual Framework

Entrepreneurial orientation is a one of interesting topic due to the belief that it is one of the key sucess factors for gaining a competitive advantage and improving firm performance. The organizational level of the model is embedded in the fact that it focuses on SMEs' performance. This is based on prior literature that indicated individual SMEs' owner have a direct impact on the behavior and effectiveness of firms (Nummela, Saarenketo, \& Puumalainen, 2004).

To test the models presented above the following hypotheses are formulated:

Entrepreneurial orientation will significantly affect business strategy among : Hypothesis1

SMEs' in Denpasar Bali

Entrepreneurial orientation will significantly affect SMEs' marketing performance : Hypothesis2

in Denpasar Bali

Business strategy will significantly affect SMEs' marketing performance in : Hypothesis3

Denpasar Bali

There is an important mediating role of business strategy on the effect of : Hypothesis4 entrepreneurial orientation toward the SMEs' marketing performance in Denpasar

Bali. 
INTERNATIONAL JOURNAL OF ACADEMIC RESEARCH IN BUSINESS AND SOCIAL SCIENCES Vol. 8, No. 11, Nov, 2018, E-ISSN: 2222-6990 @ 2018 HRMARS

\section{Methodology}

Population in this study were 2234 superior micro and small business in Denpasar (based on data from the Ministry of Cooperatives and SMEs in Bali Province, 2017). Number of samples are determined by using Slovin formula in which sampling error of 10 percent was applied in this study. The sample was determined using a non-probability sampling technique, using purposive sampling, by taking the number of entrepreneurs identified. About 95 entrepreneurs or owners of small business scale are taken as respondents of this study.

The majority of respondents in this study were male (56.8 percent), and have 35 high school education (high school) or 36.8 percent. About 31 people or 32.6 percent of respondents identified as entrepreneurs with undergraduate degrees. Only 2 people or 2.1 percent of entrepreneurs have a postgraduate degree. Furthermore, about 28 entrepreneurs or 29.5 percent of respondents are entrepreneurs who aged 37-46 years, followed by 27 people or 28.4 percent are entrepreneurs aged over 46 years. 17 people or 17.9 percent of entrepreneurs aged between 17-26 years, where this sample category has the lowest number compared to samples in other categories. The highest number of respondents with business ages criteria that run over 9 years is 34 people or 35.8 percent. While the number of respondents with a range of businesses carried out between 6 to 9 years are 25 people or 26.3 percent of sample, the criteria for the span of 1 to 3 years is 19 people or 20.0 percent of the research sample. The smallest number of respondents is entrepreneurs of 3 to 6 years of running business duration totaling 17 people or 17.9 percent.

Data collected were analyzed using Partial Least Square, regarding of the interrelationships structural model, with consideration of latent variables based on variance matrix to maximizing the explained variance of the dependent latent constructs. These method used to developing theoretical model of standard path for assessing the success drivers of certain target constructs with key relevance.

\section{Instrument}

In developing appropriate measures, it was important to recognize that small medium enterprise will behave uniquely if a relationship contains both competition and cooperation at the same time. Moreover small firms differ in a number of significant ways from their larger counterparts. Based on the literature review and an assessment of available scales, three measures were employed: entrepreneurial orientation, business strategy, and marketing performance. The items measuring the of each dimension employed five-point Likert-type response scales ( 1 = strongly disagree to $5=$ strongly agree).

Entrepreneurial Orientation. Entrepreneurial orientation is described by the process, practice and decision-making activities that drive into new entry (Dess, Lumpkin, \& Covin, 1997). Operationally this concept in this study is described as a process, practice, and decision-making activities of business actors in small micro-enterprises that encourage change.

Business Strategy. Business strategy adapted scale of Pearce \& Robinson (2007) as the main action pattern chosen to realize the organization's vision and mission. Strategies shape decision-making patterns in realizing the organization's vision. With patterned actions, small medium entrperise could 
INTERNATIONAL JOURNAL OF ACADEMIC RESEARCH IN BUSINESS AND SOCIAL SCIENCES Vol. 8, No. 11, Nov, 2018, E-ISSN: 2222-6990 @ 2018 HRMARS

mobilize and allocate organizational resources effectively. As for the operational definition, business strategy is a strategy for small and medium businesses related to low cost excellence, differentiation and focus strategy.

Marketing Performance. Ferdinand (2002) stated marketing performance is expressed in three main major values: total sales, sales growth and market share, which ultimately leads to SMEs' profit. Marketing performance is one component of firm performance. The operational definition of marketing performance is the performance of the marketing functional in small and medium enterprises based on sales growth, customer growth, market share, and profitability.

\section{Findings and Discussion}

Table 1. Mean of Variables, Standard Deviation and Intercorrelations $(n=95)$

\begin{tabular}{|c|c|c|c|c|c|c|}
\hline Variables & AVE & VAVE & $\begin{array}{l}\text { Mean } \\
\text { (SD) }\end{array}$ & 1 & 2 & 3 \\
\hline $\begin{array}{l}\text { 1.Entrepreneurial } \\
\text { Orientation }\end{array}$ & 0,739 & 0,860 & $\begin{array}{c}3.61 \\
(2.046)\end{array}$ & $(.816)$ & & \\
\hline 2.Business Strategy & 0,786 & 0,887 & $\begin{array}{c}3.73 \\
(2.928)\end{array}$ & $0,627 * *$ & $(.774)$ & \\
\hline 3.Marketing Performance & 0,785 & 0,886 & $\begin{array}{c}3.24 \\
(1.927)\end{array}$ & $0,594 * *$ & $0,537 * *$ & $(.754)$ \\
\hline
\end{tabular}

Notes: ${ }^{* *} p, 0.01 ;{ }^{*} p, 0.05$; Cronbach's alphas for each scale are italicized and shown in the diagonal

Table 1 show mean, standar deviation and reliability scores for the variables used in the analysis in sample. The means range from 3.24 to 3.73 and the standard deviations range from 1.927 to 2.928. The mean score for the business strategy was 3.56, indicating the highest average score of subjective assessment in SME. Furthermore, the mean score for entrepreneurial orientation and marketing performance were 3.61 and 3.24 .

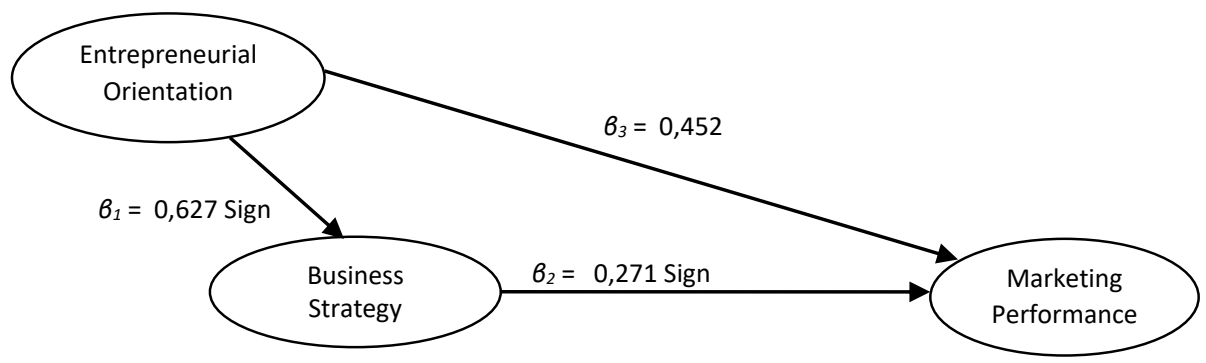

The path coefficient between entrepreneurial orientations towards business strategy found to have a positive effect of 0.627 . The value of the relationship is significant at the 0.05 level because the value of the t-statistic is greater than 1.96 which is equal to 11.8609 . This result proves the first hypothesis 1 is accepted. The path coefficient between entrepreneurial orientations towards marketing performance was found to have a positive effect of 0.452 . The value of the relationship is significant at the 0.05 level because the value of $t$-statistic is greater than 1.96 which is 4.6553 . This 
INTERNATIONAL JOURNAL OF ACADEMIC RESEARCH IN BUSINESS AND SOCIAL SCIENCES Vol. 8, No. 11, Nov, 2018, E-ISSN: 2222-6990 @ 2018 HRMARS

result proves the second hypothesis is accepted. The path coefficient between business strategy and marketing performance was found to have a positive effect of 0.271 . The value of the relationship is significant at the 0.05 level because the t-statistic value is greater than 1.96 which is 2.0528 . The path coefficient between entrepreneurial orientations towards business strategy found to have a positive effect of 0.627 . The value of the effect is significant at the 0.01 level ( $p .<0.01$ ), and because the t-statistic value is greater than 1.96 which is 11.8609 . The path coefficient value between business strategy and marketing performance was found to have a positive effect of 0.271 (p. 0.005$)$. The value is significant at the 0.01 level $(p<0.01)$ and because the t-statistic value is greater than 1.96 which is 2.0528.

The results show the indirect effect of entrepreneurial orientation on marketing performance through the micro-small business strategy; with coefficient were $0.627 \times 0.271=0.169$. While the direct effect of entrepreneurial orientation on marketing performance is 0.452 . If the coefficient value of the indirect effect is greater than the direct effect coefficient, it is said to be perfect mediation or complete mediation. Meanwhile Hair et al., (2006) determined that if the values of $B_{1}$ and $B_{2}$ are significant, but $B_{3}$ is not significant, then it can be stated as perfect mediation. While the results of the calculation of the significance of the mediating role of business strategy on the effect of entrepreneurial orientation toward marketing performance by analyzing the value of beta coefficients and standard errors on each path (entrepreneurial orientation $\rightarrow$ business strategy; entrepreneurial orientation $\rightarrow$ marketing performance, business strategy $\rightarrow$ marketing performance).

Finding show that there is a significant mediation effect of the business strategy on the effect of entrepreneurial orientation on the SMEs' marketing performance, with a z score $=2.02127$ and a $p$ value of 0.022 . It can be concluded that business strategies could provide an important mediating role in the effect of entrepreneurial orientation on the SMEs' marketing performance. This result proves the fourth hypothesis is accepted. It can be concluded that there is an important mediating role of the business strategy on the effect of entrepreneurial orientation on the marketing performance of superior micro-small businesses in Denpasar Bali.

Entrepreneurship is the process of creating value by combining resources. Entrepreneurs are required to consider economies of scale, ability to lock customers, competitor growth, limited resources, and managerial decision making that are important for the development and future of the business. Therefore, entrepreneurial orientation is a series of business beliefs and philosophies. This is a form of organizational practice as a moderator in playing an important role promoting output at the company and employee level. Entrepreneurial orientation still requires learning systems and organizational practices to facilitate high-level learning and innovation (Backer \& Sinkula, 2009). While Morgan \& Berthon, (2008) have proposed the importance of contingency perspectives in explaining how entrepreneurial orientation could improves firm performance. Entrepreneurial orientation illustrates the importance of independence from action, willingness to explore ideas, markets, and new efforts to support competitive advantage in the market. Covin \& Slevin, (1991) argue that entrepreneurial orientation affects not only the creation of new businesses, but also affects firm performance. Therefore, entrepreneurial orientation is a form of strategic orientation that is very important for the existence of the firm. But it should be underlined that the pattern of relations between entrepreneurial orientations has not considered as environmental factors. That is, 
INTERNATIONAL JOURNAL OF ACADEMIC RESEARCH IN BUSINESS AND SOCIAL SCIENCES Vol. 8, No. 11, Nov, 2018, E-ISSN: 2222-6990 @ 2018 HRMARS

the strength of the relationship between entrepreneurial orientation and performance depends on the characteristics of external environment and internal characteristics of small medium enterprise in Denpasar Bali.

Therefore, the relationship between entrepreneurial orientation and performance may seem more complex than causality relationships which have a simple effect. On the other hand entrepreneurs of small medium enterprise who have a strong entrepreneurial orientation are more likely to take advantage of technology than their other counterparts because they are more likely to take innovative attitudes in supporting efforts to provide differentiation in the business and products being run. The leading small micro business actors are more likely to take advantage of technological benefits because of their tendency to help businesses stay competitive on the market (Verreynne \& Meyer, 2010).

Research findings generally show that the ability to innovate, always proactive and the courage to take risks plays an important role in supporting business strategies that are applied to the superior micro small businesses in Denpasar Bali. Many of the superior small businesses are feels challenged to maintain the competitive advantage they have in order to remain competitive with large companies through innovation and continuous learning (Ejdys, 2016; Wagner \& Hansen, 2005). This shows the importance of innovation in strengthening business strategies carried out by small and medium micro enterprises in Denpasar Bali.

\section{Conclusion}

The importance of knowledge in entrepreneurial orientation and business performance has been widely recognized by previous empirical results. As a business entity that has a high degree of entrepreneurial orientation is tend to involve the selection of an appropriate strategy and to seek further development of business performance. This is evidenced that the entrepreneurial orientation of entrepreneurs in the small medium enterprise in Denpasar Bali is more likely to treat innovation as the most important thing. This is in line with the selection of business strategies implemented, which is differentiation strategy as the most important thing that is considered by the SMEs' entrepreneur in Denpasar Bali. This differentiation strategy will lead to profit creation due to increased market capitalization. Therefore for the SMEs' entrepreneur in Denpasar Bali, market control is the most important thing in reflecting the performance achieved, especially in terms of marketing performance.

Clearly, advocates of the need for a small firm who operated by entrepreneur to possess a strong entrepreneurial orientation have a "normative bias." But it must be noted that using a business model approach to entrepreneurship can make the EO concept more realistic and closer to practice. Even so, the entrepreneurial activity is often initialized in a specific component. The achieved results confirmed that, entrepreneurial orientation is the most dominant factor in affecting SMEs' performance. Just like entrepreneurs can use networks to help them improve their competence in decision making and in delivering marketing activity, in long term this would increase SMEs' performance.

Although there are still limitations inherent in the informant, based on all the field phenomena and their analysis, it could be said that they have been able to build business institutions based on 
INTERNATIONAL JOURNAL OF ACADEMIC RESEARCH IN BUSINESS AND SOCIAL SCIENCES Vol. 8, No. 11, Nov, 2018, E-ISSN: 2222-6990 @ 2018 HRMARS

their entrepreneurial orientation. Entrepreneurial orientation construction becomes the basis of economic institutions for superior of small businesses in Denpasar Bali.

There are several contributions and implications for researchers from our study. Based on our theoretical investigation of SMEs in Denpasar Bali, the mediating impact of environmental uncertainty needs to be expanded to include the uncertainty in the domestic market and the foreign market in which the SME is operating. Also, consideration should be given to firms operating outside of Denpasar Bali.Future research, as an extension of this study, needs to focus on obtaining data over time. A longitudinal study would be valuable because the failure rate of the SME could be taken into consideration.

\section{Acknowledgment}

The authors would like to express their gratitude to all participants who took part in this study and the three anonymous reviewers for their suggestions during the development of this article.

\section{Corresponding Author}

\section{Ida Bagus Agung Dharmanegara}

Head of Department of Management, Email: gusdhewun@gmail.com

Faculty of Economic, Warmadewa University of Denpasar, Bali, Indonesia

\section{References}

Backer, W. E., \& Sinkula, J. M. (2009). The complementary effects of market orientation and entrepreneurial orientation on profitability in small business. Journal of Small Business Management, 47(4), 443-464.

Berger, A. N., Hasan, I., \& Zhou, M. (2010). The Effects of focus versus differentiation on firm performance : Evidence from Chinese Firms. Evident from Chinese Firm, 34, 1417-1435.

Best, R. J. (2009). Market-Based Management: Strategy for Growing Customer Value and Profitability. New Jersey: Pearson Education Inc.

Blackburn, R. A., Hart, M., \& Wainwright, T. (2013). Small business performance: business, strategy and owner-manager characteristics. Journal of Small Business and Enterprise Development, 20(1), 8-27. https://doi.org/10.1108/14626001311298394

Covin, J., \& Slevin, D. (1991). A conceptual model of entrepreneurship as firm behavior. Entrepreneurship Theory and Practice, 16(1), 7-24.

Dess, G. G., Lumpkin, G. T., \& Covin, J. G. (1997). Entrepreneurial Strategy Making and Firm Performance: Test of Contingency and Configurational Models. Strategic Management Journal, 18(9), $677-695$.

Ejdys, J. (2016). Entrepreneurial Orientation vs. Innovativeness of Small and Medium Size Enterprises. Journal of Engineering, Project, and Production Management, 6(1), 13-24.

Ferdinand, A. (2002). Marketing Strategy Making: Proses dan Agenda Penelitian. Jurnal Sains Pemasaran Indonesia, 1(1), 1-22.

Ferreira, J. J., Raposo, M. L., Rodrigues, R. G., Dinis, A., \& Paco, A. do. (2012). A model of entrepreneurial intention: An application of the psychological and behavioral approaches. Journal of Small Business and Enterprise Development, 19(3), 424-440. 
INTERNATIONAL JOURNAL OF ACADEMIC RESEARCH IN BUSINESS AND SOCIAL SCIENCES

Vol. 8, No. 11, Nov, 2018, E-ISSN: 2222-6990 @ 2018 HRMARS

https://doi.org/10.1108/14626001211250144

Gilmore, A. (2011). Entrepreneurial and SME marketing. Journal of Research in Marketing and Entrepreneurship, 13(2), 137-145. https://doi.org/10.1108/14715201111176426

Hair, J. F. J., Black, W. C., Babin, B. J., Anderson, R. E., \& Tatham, R. L. (2006). Multivariate data analysis. New Jersey: Pearson / Prentice Hall.

Kotler, P., \& Keller, K. L. (2012). Marketing Management. Essex: Pearson Education Limited.

Lumpkin, G. T., \& Dess, G. G. (1996). Clarifying the Entrepreneurial Orientation Construct and Linking It to Performance. The Academy of Management Review, 21(1), 135-172.

Lumpkin, G. T., \& Dess, G. G. (2001). Linking two dimensions of entrepreneurial orientation to firm performance: the moderating role of environment and industry life cycle. Journal of Business Venturing, 16, 429-451.

Lyon, D. W., Lumpkin, G. T., \& Dess, G. G. (2000). Enhancing entrepreneurial orientation research: Operationalizing and measuring a key strategic decision making process. Journal of Management, 26(5), 1055-1085.

Morgan, R. E., \& Berthon, P. (2008). Market Orientation, Generative Learning, Innovation Strategy and Business Performance Inter-relationship in Bioscience Firms. Journal of Management Studies, 45(8), 1329-1353.

Nummela, N., Saarenketo, S., \& Puumalainen. (2004). Towards, Attitude Internationalization?, Internationalization- A prerequisite for successful Internationalization. Canadian Journal $O F$ Administrative Sciences, 21(1), 51-64.

Pearce, J., \& Robinson, R. B. (2007). Strategic Management Formulation, Implementation, and Control, 10th Ed. McGraw-Hill.

Sagie, A., \& Elizur, D. (1999). Achievement Motive an Entrepreneurial Orientation: A Structural Analysis. Journal of Organizational Behavior, 20(3), 375-387.

Suci, R. P. (2009). Peningkatan Kinerja Melalui Orientasi Kewirausahaan, Kemampuan Manajemen, dan Strategi Bisnis. Jurnal Manajemen Dan Kewirausahaan, 11(1), 46-58.

Verreynne, M.-L., \& Meyer, D. (2010). Small business strategy and the industry life cycle. Small Business Economics, 35(November 2008), 399-416. https://doi.org/10.1007/s11187-008-91653

Wagner, E. R., \& Hansen, E. N. (2005). Innovation in large versus small companies: Insights from the US wood products industry. Management Decision, 43, 837-850.

Wiklund, J. (1999). The sustainability of the entrepreneurial orientation - performance relationship. Entrepreneurship Theory and Practice, 24(1), 37-48.

Wiklund, J., \& Shepherd, D. (2005). Entrepreneurial orientation and small business performance: A configurational approach. Journal of Business Venturing, 20, 71-91. https://doi.org/10.1016/j.jbusvent.2004.01.001 